\title{
UPRAVLJANJE LJUDSKIM RESURSIMA - IZAZOV NOVOG MILENIJUMA
}

\section{HUMAN RESOURCES MANAGEMENT - THE CHALLENGE OF THE NEW MILLENNIUM}

\author{
Zoran Ristić \\ „MB“ Univerzitet, Poslovni i pravni fakultet, Beograd, Srbija
}

Aleksandar Damnjanović

„MB“ Univerzitet, Poslovni i pravni fakultet, Beograd, Srbija

CMESTE

JEL kategorija rada: $\mathbf{H 1 2 ,}$ M12

\begin{abstract}
Apstrakt
Da su ljudski resursi najvažniji faktor u u poslovanju svake organizacije razvijeni svet odavno zna. Zato im i treba posvetiti najveću pažnju. Međutim, u savremenom svetu visoke tehnologije, često se dešava da se velika pažnja posveti elektronskim sistemima i da se zaboravi koliko su ljudi zapravo važni. Ovim tekstom se želi istaći značaj dobrih međuljudskih odnosa u organizaciji i ukazati da su zaposleni, koji dobro obavljaju svoj posao, najvrednija imovina koju ona ima, da je snaga svakog preduzeća $u$ sposobnosti svih zaposlenih, da su zaposleni ti koji čine preduzeće onim što ono stvarno jeste, oni su ti koji daju život preduzeću i omogućavaju njegovo funkcionisanje. U radu se naglašava da je napuštanje starih, tradicionalnih i uvođenje novih savremenih stilova upravljanja pretpostavka uspešnog tržišnog nastup svake organizacije $i$ analizira stanje u ovoj oblasti u našim preduzećima. Sa ciljem naglašavanja novih uloga menadžera pažnja se usmerava na njegove liderske i trenerske sposobnosti, te komunikacione sposobnosti koje predstavljaju ključ za uspešnu saradnju i veću motivisanost zaposlenih. Preporuke i zaključci koji su sadržani u ovom radu mogu biti osnova za dalja istraživanja, sa ciljem da se obezbedi bolja teorijska osnova za efektivno i efikasno upravljanje ljudskim resursima u suočavanju sa brojnim izazovima novog milenijuma.
\end{abstract}

Ključne reči: motivacija, integracija, kooperacija, komunikacija, timski rad

\begin{abstract}
Adresa autora zaduženog za korespodenciju Zoran Ristić

恝zoranris@yahoo.com
\end{abstract}

The developed world has long known that human resources are the most important factor in the business of any organization. That is why he should be given the greatest attention. However, in the modern world of high technology, it often happens to pay attention to electronic systems and to forget how important people really are. With this text he wants to emphasize the importance of good interpersonal relations in the organization and point out that employees who do their job well are the most valuable assets it has, that the strength of every company is in the abilities of all employees, that employees make the company 
what it really is. they are the ones who give life to the company and enable its functioning. The paper emphasizes that the abandonment of old, traditional and the introduction of new modern management styles is a prerequisite for a successful market presence of any organization and analyzes the situation in this area in our companies. In order to emphasize the new roles of managers, attention is focused on his leadership and coaching skills, and communication skills that are the key to successful cooperation and greater motivation of employees. The recommendations and conclusions contained in this paper can be the basis for further research, with the aim of providing a better theoretical basis for effective and efficient human resource management in facing the many challenges of the new millennium.

Keywords: motivation, integration, cooperation, communication, teamwork.

\section{UVODNE NAPOMENE}

Uspešno poslovanje je bilo i ostalo cilj svakog preduzeća. Ono što se vremenom menjalo, to su načini na koje je ono ostvarivano. Nekada je tehnologija bila ključna, nekada metode rada, a danas je to veština i sposobnost menadžmenta da pridobije zaposlene za svoju ideju, viziju, strategiju. Opstanak i uspeh danas, sve više zavisi od svakodnevne mobilizacije inteligencije zaposlenih u preduzeću. Zadatak menadžmenta da stalno stvara uslove za ispoljavanje i korišćenje njihovih potencijala postaje sve važniji, a za očekivati je da će u budućnosti to biti još izraženije.

Procesi modernizacije poslovanja i upravljanja, napuštanja tradicionalnih, zastarelih i uvođenja novih, savremenih stilova upravljanja - i to su procesi tranzicije. Na njih mnogi zaboravljaju, a bez njih svaka druga transformacija teško može da bude uspešna. Zato osposobljavanje preduzeća za kvalitetan tržišni nastup, mora da uključi i transformaciju upravljanja (promenu shvatanja uloge menadžmenta) i uvođenje savremenog koncepta menadžmenta, koji afirmiše moderne uloge menadžera, kakve postoje u svetu razvijene tržišne privrede. Potrebno je uneti nova znanja iz ove oblasti i proširiti in sve do operativnih nivoa.

Dugo godina je uspeh bio zasnivan na efikasnom upravljanju "hard” (tvrdim) dimenzijama organizacije kao što su tehnologija, organizaciona struktura, strategija. Danas se, međutim, u organizaciji i menadžmentu uspešnih firmi težište prenosi na "soft” (meke) dimenzije organizacije kao što su: kultura, klima, satisfakcija, leadership (vođenje), motivacija, sistem nagrađivanja, komunikacije... Nova tehnologija nije zasnovana na fizičkom radu, nego na znanju, inovativnosti, kreativnosti. Za to je potrebna adekvatna motivacija zaposlenih i demokratska atmosfera. Zbog toga su preduzeća bila prisiljena da materijalne stimulanse, pritisak i kontrolu zamene „finim mehanizmima” humanizacijom i demokratizacijom ambijenta na poslu. Trebalo je stvoriti uslove koji će zadovoljiti novu generaciju zaposlenih i nov način gledanja na posao. Neke od ključnih reči postaju: međuljudski odnosi, kooperacija, timski rad... Naravno da preduzeće koje je prihvatilo tržišni koncept mora biti okrenuto prema svojoj ulozi u zadovoljavanju potreba potrošača na tržištu i uspostavljanju dobrih veza sa svim svojim stejkholderima, a ne isključivo prema sebi $\mathrm{i}$ internim odnosima. Uostalom, interni odnosi će se uvek efikasnije rešavati ako je preduzeće orjentisano na ostvarivanje svoje uloge u privredi i društvu. Ali ono što svaki menadžment mora da zna, to je da se zaposleni ne mogu više smatrati robom, oni su kapital koji znači stručnost, ponos, požrtvovanost i određene potrebe koje radna sredina treba da zadovolji.

\section{ODNOSI U ORGANIZACIJI - JUČE, DANAS, SUTRA}

U savremenom konceptu menadžmenta centralno mesto zauzimaju ljudi. Uostalom, on se vrlo često i definiše kao uticaj na ponašanje zaposlenih radi ostvarivanja ciljeva organizacije. Orjentacija na ljude, kao na dinamičan elemenat organizacije i upravljanje ljudskim potencijalima, postaje dominantan zadatak menadžmenta i strateška orjentacija savremenog poslovanja. Oni postaju ključan element (resurs) koji može da znači razliku između uspeha i neuspeha.

Disciplina i čvrsta ruka i komandno - kontrolne metode prošlosti, tipa „ćuti i radi kako gazda kaže", koje su nekada davale dobre rezultate više ne prolaze i nisu efikasne. Tradicionalni mentalni modeli shvatanja uloge menadžera, po kojima upravljanje znači odlučivanje o tome šta i na koji način će se raditi i kako će se kontrolisati 
(Planiranje - Organizovanje - Naređivanje Kontrola) postaju prošlost, jer to više nije njihova primarna (glavna) uloga. Umesto toga zaposlene treba ovlastiti, podržavati in $u$ onome što rade $i$ pustiti in da rade (Upravljati - Ovlastiti - Pratiti Podržavati). Centralizovane, hijerarhijski struktuirane organizacije postaju nepodesne $\mathrm{i}$ moraju biti zamenjene sa više podržavajućim i stimulativnim mehanizmima upravljanja. Umesto hijerarhijske, stvara se organizacija u kojoj je akcenat na intenzivnim kontaktima zaposlenih $\mathrm{i}$ razmeni informacija. Unutrašnje organizacione granice postaju sve nejasnije, organizacija i koordinacija aktivnosti putem detaljnog planiranja ima sve manji značaj, a sve važnije postaje da menadžment razvija „mekšu” veštinu (mudrost) da se od svakog pojedinca dobije ono što je najbolje za organizaciju. Stvara se organizacija, koja obezbeđuje nesmetan protok informacija, podstiče preuzimanje odgovornosti i interakcije među jednakima, neformalnu komunikaciju i ispoljavanje liderstva nezavisno od hijerarhijskog nivoa.

Kakva je situacija kod nas? Gde se mi nalazimo $\mathrm{u}$ odnosu na svet razvijenih? $U$ mnogim preduzećima moć je uglavnom skoncentrisana na vrhu, ostali nivoi menadžmenta, stručne službe i zaposleni imaju nedovoljno informacija i sasvim male mogućnosti da se uključe $u$ ono što se dešava u preduzeću. Da sve bude još gore, mnogi ovo smatraju uspešnim, efikasnim menadžmentom.

Trenutno preovlađujući autokratski načini upravljanja i nadmoćni stil menadžmenta moraju da postanu prošlost, oni moraju da se transformišu. Neophodne su nove metode, stilovi, načini upravljanja. Uspeh je mnogo lakše ostvariti kada svi rade zajedno kao jedan sistem, sa ciljem da svako bude pobednik, da svako bude "na dobitku” - zato partnersko uobličavanje života u organizacijama i saradnja, stvaranje gipkijih, neposrednijih, toplijih međuljudskih odnosa postaje jedan od najvažnijih zadataka koji treba ostvariti. Uprava ne sme biti "daleko" od zaposlenih, između nje i zaposlenih nikada ne sme da postoji osećaj „oni i mi“. (Ristić, 2005, str. 228)

Interne odnose koje odlikuju briga za svakog zaposlenog, opuštena atmosfera i poverenje u međusobnim odnosima stvara menadžment koji:
- Shvata značenje ciljeva preduzeća i prenosi ih zaposlenima, podučava ih da shvate da njihov rad podržava ove ciljeve;

- Pomaže zaposlenima da vide sebe kao sastavne delove $u$ jednom sistemu, da rade $u$ pravcu optimizacije napora usmerenih ka postizanju zajedničkog cilja;

- Shvata da se ljudi međusobno razlikuju, zato nastoji da za svakog stvori osećaj zainteresovanosti, koristi, izazova i zadovoljstva na poslu;

- Neprestano uči i na to podstiče druge, on je trener i savetnik, a ne sudija;

- Više se oslanja na svoje znanje, snagu svoje ličnosti i snagu ubeđivanja, nego na autoritet svoje funkcije;

- Stvara veru, poverenje, okruženje koje podstiče slobodu i inovativnost.

Savremene organizacije shvataju da njihov uspeh u najvećoj meri zavisi od sposobnosti da razviju i zadrže talentovanu radnu snagu, što je značajan faktor u razvoju visokih performansi. Zaposleni više ne predstavljaju puke izvršioce određenog posla, nego vitalni resurs koji zahteva veću pažnju i stalno razvijanje. Zato je upravljanje ljudskim resursima veoma važno za uspeh bilo koje organizacije, danas mnogo više neko ikada ranije. (Radić \& Radić, 2015, str. 353)

\section{MENADŽER - TRENER I SAVETNIK}

Često menadžer i pored nesporne inteligencije i predanog rada, ne postigne uspeh, zato što ne shvati da njegovi napori predstavljaju odraz napora ljudi sa kojima radi i ne posveti dovoljno vremena razgovorima sa njima, osluškujući njihove probleme, stavove, očekivanja, motive, želje, interese. Posao menadžera je da mobiliše i aktivira energiju svih zaposlenih i usmerava individualne napore ka zajedničkom cilju, da stvori okruženje koje podržava etički zdravo ponašanje i uliva osećaj zajedničke odgovornosti, da stvori uverenje kod zaposlenih da rade $u$ uspešnoj, afirmisanoj, značajnoj i dobroj firmi. A to može da čini jedino podsticanjem neposredne, direktne i otvorene komunikacije, rušenjem zidova između službi i stvaranjem boljeg razumevanja za međusobne aktivnosti, stvaranjem uslova za neformalne razgovore između zaposlenih bez obzira na njihov status i položaj, neprestanim učenjem, napredovanjem, 
efikasnim programima obuke i motivacije, podsticanjem participacije, razvijanjem samokontrole i samousmerenja kod zaposlenih.

Poput sportskog trenera, dobar menadžer traži i pronalazi ono najbolje u svakom čoveku, podstiče zaposlene da rade zajedno u timu, preuzmu odgovornost i participiraju u donošenju odluka, spreman je da podigne moral, uvek ima ,otvorena vrata", obilazi zaposlene na njihovim radnim mestima, želi da zna njihove probleme, ne zatvara se u „tvrđavu” svoje kancelarije, dobar je slušalac, spreman da čuje svačije mišljenje, pošten i otvoren prema svima, uporan je ali $i$ tolerantan, ne nameće silom svoje mišljenje $i$ spreman je da podnese tuđe neslaganje sa svojim stavovima, zna imena svojih saradnika $i$ ima poverenje u njih, nije arogantan, otvoren je za komunikaciju i ne blokira informacije, iskren je i principijelan, nikada ne radi iza leđa i ne ogovara saradnike, eventualne sukobe pre rešava „oči u oči", a ne preko papira, izveštaja, komisija ili trećih osoba, ne manipuliše ljudima i ne govori im samo ono što žele da čuju. (Rajkov \& Sajfert, 1999, str. 59) Takvog menadžera karakterišu i sledeće osobine: inteligentnost, inspiracija, iskrenost, poštenje, hrabrost, maštovitost, fleksibilnost, spremnost da sarađuje i pomogne, sposobnost da stvori i vodi efikasan tim, energičnost, inovativnost, sposobnost stvaranja vizije, harizmatičnost, demokratičnost, obrazovanost, kreativnost, takmičarski duh, samouverenost, samokontrola, hladnokrvnost, mirnoća, vedrina, optimizam...

Skladni odnosi između uprave i zaposlenih su u interesu i jednih i drugih. Saradnja, poštovanje i poverenje, treba da čine okosnicu takvih odnosa. To omogućava timski rad, kreativnost i inovativno ponašanje zaposlenih. I danas ima onih koji misle da im njihov položaj dopušta osornost i da zapovedaju, onih koji ne primećuju svoje saradnike ili primećuju samo nekolicinu najbližih saradnika. Ipak, zapovedanje je možda priličilo plemenskim vođama, ali ne i poslovnim menadžerima, a i dani kada se verovalo da je dernjava isto što i čvrstina, su iza nas. (Charney, 1996, str. 27) Menadžeri nisu privilegovana klasa, oni su članovi timova a ne šefovi podređenima, oni sve više preuzimaju ulogu savetodavca, umesto pretnji i kazni treba da afirmišu inicijativu, ohrabruju, uče i inspirišu, a ne da ih obeshrabruju, zvuče negativno i kritikuju; menadžer treba da stvara, a ne da ruši, bez nestrpljivosti, bez vikanja, bez histerije.

Kroz bolju integrisanost zaposlenih u kolektiv i njihovih interesa u ciljeve preduzeća, kreira se takav interni ambijent koji obezbeđuje dodatnu motivisanost i pripadnost zaposlenih. Zaposleni trebaju da osećaju određen stepen nezavisnosti, ali moraju istovremeno da se osećaju kao deo tima koji deli isti sistem vrednosti, verovanja i ideala, kolektivni duh i odanost firmi, osećaj zajedništva i pripadnost jednoj „porodici”. Formirano osećanje pripadnosti preduzeća i timu, razvija čvršće emotivne veze među zaposlenima, smisao za drugarstvo, prijateljstvo, uzajamno pomaganje i konstruktivne zajedničke akcije. Ovo stvara sigurnost i želju svakog zaposlenog da se identifikuje sa svojim preduzećem i motiviše ga da svoje sposobnosti i napore maksimalno usmeri u pravcu ostvarivanja planirane strategije i ciljeva poslovanja. Zato zaposlene treba uključiti, pojačati njihovo osećanje ponosa na preduzeće, razviti osećanje da je njihovo dobro funkcionisanje važnije nego vođenje preduzeća sa vrha. Na taj način se stvaraju lojalni članovi organizacije i osećanje kod svakog člana da je on potreban preduzeću, ali i da je preduzeće potrebno njemu, povećava njihov interes za posao, naređenja se prihvataju kao svoja, stvara se veoma pogodno psiho - socijalno okruženje (pobednički ambijent) u kome se jedino mogu, uz uvažavanje ličnosti svakoga, pokrenuti stvaralački potencijali zaposlenih i njihova inicijativa.

Upravljati ne znači baviti se greškama ljudi, već baviti se njihovim idejama, njihovom kreativnošću, potencijalima. Top menadžment, danas, sve manje podseća na vrh piramide, a sve više predstavlja snažan centar oko koga su skoncentrisani spoljašnji krugovi, u čijoj je osnovi timski rad. Umesto krute hijerarhijske strukture sa značajnim socijalnim distancama, stvara se organizacija u kojoj je akcenat na intenzivnim kontaktima zaposlenih i razmeni informacija. Međusobni odnosi postaju više prijateljski nego formalni, ali sa puno respekta.

\section{KOMUNIKACIJE ZAPOSLENIH - KLJUČ ZA SARADNJU}

Ljudi se rađaju sa potrebom da imaju veze i odnose sa drugim ljudima. Menadžment mora da 
ima dovoljno znanja i umeća da ostvari „vezu” sa zaposlenima, a načina da se to učini je mnogo. Neki od najčešćih su: više socijalnih programa za zaposlene i njihove porodice, više informacija za zaposlene, interne publikacije, audiovizuelna sredstva (interni radio, televizija...), intranet $i$ elektronska pošta, organizovanje diskusija povodom određenih pitanja, internih događaja kojima se podstiče druženje zaposlenih (sportska takmičenja, svečanosti, razne sekcije...), programa usavršavanja i specijalizacije kroz seminare, predavanja, kreativne radionice, stručne ekskurzije i studijske posete, organizovanje humanitarnih akcija, susreta penzionera, književnih večeri, zajedničkih izleta i putovanja, posete top menadžmenta proizvodnim postrojenjima, odavanje priznanja i nagrada za dugogodišnji rad i vernost preduzeću...

Dobar primer menadžmenta koji je zasnovan na široko postavljenim komunikacijama i saradnji je Japanski sistem ringi (menadžment pomoću konsenzusa), koji pruža zaposlenima priliku da diskutuju i reaguju na predloge top menadžmenta, akcenat je na grupnom delovanju, harmoniji, otvorenim komunikacijama i dobrovoljnom učestvovanju. Menadžment ne donosi odluke sam, kolektivno se diskutuje, predlaže, odlučuje. $U$ proces odlučivanja, planiranja i izvršenja zadataka uključuju se svi zaposleni.

Ističući značaj internih komunikacija, Cy Charney sugeriše menadžmentu šta treba da čini kako bi dobio više od svog osoblja, proširio svoje vidike i stekao čvršće tlo pod nogama (Charney, 1996, str. 40-41 i 50):

- Uključite ljude u promene koje sprovodite, pitajte in za mišljenje - tako se oni osećaju vrednijim i otvoreniji su za preuzimanje obaveza;

- Saslušajte ono što žele da vam kažu, pokušajte da razumete njihove misli i osećanja (interese, ciljeve, brige);

- Vodite računa da komunikacija bude otvorena i objektivna, kako biste sprečili moguće sumnje i nezadovoljstva;

- Bavite se pitanjima o kojima nije lako razgovarati, inače će problem postati ozbiljniji;

- Osluškujte, morate imati sluh za glasine, kako bi ste problem identifikovali na vreme, pre nego što se otme kontroli;
- Podstaknite ljude da komuniciraju sa vama, olakšajte im da mogu doći do vas, upravljajte šetajući se, neka vas vide;

- Podstaknite ideje saradnika prihvatanjem dobrih sugestija, zahvalite im se na sugestijama, čak i ako se uvek ne slažete sa njima;

Da bi bolje razumeli značaj komunikacije unutar organizacije, treba znati njenu funkciju. U literaturi se najčešće nekoliko ovih funkcija (Bećirović, Ljajić, Elfić-Zukorlić, \& Smailović, 2020, str. 440):

- Kontrola;

- Motivisanje

- Emocionalno izražavanje;

- Informisanje

Ove četiri funkcije jasno pokazuju poseban značaj komunikacije unutar organizacije, a pogotovo između menadžera i zaposlenih. Može se lako uočiti da će pogrešna komunikacija dovesti do problema unutar organizacije.

Zidovi kancelarija se moraju „porušiti”, mistika hijerarhije se mora razbiti, menadžment se mora učiniti pristupačnijim. Samo onaj menadžer koji ima poverenje u svoje saradnike i ovi u njega, može da računa na uspeh i blagovremeno izvršavanje zadataka. Zaposleni neće reći šta misle i neće rado prihvatati tuđe ideje, ako se prvo ne stvore temelji, a oni se sastoje od istinskog poverenja i zajedničkog interesovanja.

U uslovima globalizacije, sve više organizacija koristi savremene informaciono komunikacione tehnologije, pa je ovo imalo značajne implikacije na organizaciono okruženje I funkcionisanje timova u organizacijama. Upravo zahvaljujući mogućnosti da zaposleni komuniciraju bez fizičkog prisustva, se češće su forme virtuelnih timova. (Bećirović, Ljajić, Elfić-Zukorlić, \& Smailović, 2020, str. 440)

\section{MOTIVISANI NAJVREDNIJI PREDUZEĆA \\ LJUDI RESURS}

U savremenim uslovima menadžerima je na raspolaganju niz teorijskih i praksom potvrđenih istraživanja strategija motivacije ljudskih potencijala, kao što su finansijska stimulacija, obogaćivanje posla, participacija zaposlenih, fleksibilno radno vreme, priznanja i javne 
pohvale, usavršavanje, razvoj karijere... Motivisanje i adekvatno nagrađivanje postali su ključni zadaci i funkcije menadžmenta ljudskih potencijala, a presudan faktor u motivisanju jesu upravo menadžeri. (Nićin, Nićin, \& Grbić, 2014)

Ako je upravljanje, kao što je isticala Meri Parker Folet sposobnost da se stvari obave preko ljudi, onda za vrhunsko poslovanje ljudski resursi imaju višedimenzionalnu ulogu, a uspešno upravljanje njima postaje ključ uspeha svakog preduzeća. Sadržaj koncepta upravljanja ljudskim resursima pre svega podrazumeva:

- Kompetentnost zaposlenih, visok nivo njihove radne sposobnosti, veštine, znanja;

- Prihvatanje obaveze zaposlenih da izvrše svoje zadatke, lojalnost organizaciji i visoka motivisanost;

- Podudaranje mišljenja, htenja, deljenje vizije, planskih ciljeva uprave i zaposlenih na svim nivoima organizacije.

Sa svojim znanjem, sposobnostima, navikama i iskustvom zaposleni su jedini misaoni i najznačajniji element procesa rada, a ostvareni rezultati su proizvod njihovih sposobnosti, znanja, veština, ličnih osobina, vrednosti, motivacije $i$ organizacionog ambijenta. Zato se filozofija poslovanja uspešnih preduzeća danas, u odnosu na onu iz prošlosti, menja i sve više zasniva na sledećim principima (Inić, 2001, str. 2):

- Radi, živi, voli, uči - umesto samo radi, radi, radi;

- Traži značenje i novac - umesto samo novac;

- Izgradi mrežu odnosa - umesto hijerarhije moći;

- Posao i porodica - umesto posao ili porodica;

- Ne čini zlo - umesto cilj opravdava sredstva.

Promene koje je uslovila globalizacija (rastuća konkurencija, internacionalizacija poslovanja, tehnološke inovacije...) izmenila je koncept, strukturu i izgled tradicionalne organizacije. Organizacije u kojima ljudi rade, neprestano se menjaju i razvijaju, stvarajući nove trendove i probleme koji zahtevaju razmatranje i rešavanje. (Damnjanović, Suša, Škunca, Milenković, \& Ristić, 2012, str. 36)

Sve ovo je dovoljan razlog za postavljanje pitanja: Koje su osnove konkurentske prednosti? Da li su to proizvod ili usluga, tehnologija, zaštićena ili tržišta, dostupnost svežeg kapitala, ekonomija veličine proizvodnje ili ...motivisani ljudi!?
Stimulisanje zaposlenih na angažovaniji rad, vrši se ekonomskim i neekonomskim stimulansima. Ekonomski stimulansi su efikasniji u uslovima nedovoljno razvijenog životnog standarda, ali njihov značaj postepeno opada sa podizanjem nivoa životnog standarda i oni ustupaju mesto neekonomskim stimulansima (atmosferi na poslu, napredovanju, društvenom statusu...).

Ne postoji jedinstven način da se ljudi motivišu, različite ljude pokreću različite stvari, svako ima svoj način razmišljanja i obavljanja poslova. Motivacija nije nešto što može de se obezbedi prostim „njihanjem šargarepe ispred zeca”. Mnogo je razloga zašto ljudi rade, i u traženju odgovora na to pitanje najveća greška koja se može napraviti jeste pretpostaviti da svi ljudi žele isto. Motivisano osoblje se pre svega stvara:

- Uvažavanjem osnovnih želja i pojedinačnih reakcija zaposlenih, davanjem većeg stepena lične odgovornosti, učestvovanjem u formulisanju ciljeva i njihovoj realizaciji;

- Pružanjem podstreka u vidu nagrada, putovanja, statusa;

- Utvrđivanjem jasnih i prihvatljivih ciljeva, koji pružaju okvir za zajednički osećaj namere;

- Pružanjem adekvatnog programa treninga za upravu i zaposlene.

Zaposleni redovno međusobno komuniciraju i vremenom stvaraju jednu posebnu atmosferu, jedno posebno emotivno i intelektualno okruženje specifično baš za tu grupu ljudi. Ono se sastoji od nekih zajedničkih načela i pravila ponašanja, stavova, verovanja, moralnih i etičkih normi, običaja, navika, načina obraćanja, motiva, rituala, mitova, heroja, anegdota, tabua..., sve to odslikava i stvara jednu posebnu kulturu preduzeća. Na njoj se gradi njegov kredibilitet, imidž (ugled) i reputacija. Ona definiše preduzeće i direktno utiče na poslovni uspeh i njegovu konkurentnost. (Ristić, 2005, str. 147)

Kultura preduzeća, tj. način na koji je organizovano, kako misli i na koji način se ponaša, osnova su njegovog uspeha. Ona prožima celinu organizacije transformišući se u određene načine reagovanja, kako $u$ internim tako i u odnosima sa eksternim subjektima. Iz nje proističu vrednosti, klima i ponašanje. Njeni osnovni načini ispoljavanja su klima, ambijent, atmosfera koja vlada među zaposlenima, izgled $i$ uniforme zaposlenih, bedževi, identifikacione 
kartice, pojava samih zaposlenih (da li su uredni, obrijani, kojim se manirima služe...), izgled rokovnika, privezaka, pepeljara, kalendara, fascikli... Snažna i jedinstvena kultura olakšava i ubrzava proces koordinacije između zaposlenih (rešava problem interne integracije). Ona je vrlo efikasan mehanizam kontrole ponašanja zaposlenih, nekada snažniji od formalnih propisa ili direktnog nadzora.

Zdrava, podsticajna i kreativna klima, uzajamno poverenje i tolerancija, visok radni moral, zajedničko odlučivanje i rešavanje problema obezbeđuju povoljne uslove za ispoljavanje svake individue, na način na koji se postižu najbolji rezultati u radu. Takvu klimu karakteriše atmosfera otvorenosti rasprave o problemima, iznalaženja novih ideja i najboljih rešenja, umesto stalnog nametanja nečijih gotovih rešenja. Nezdrava, Ioša, represivna klima destimuliše inicijativu, radni moral i drastično umanjuje ostvarene rezultate. Najčešće posledice takve klime su neformalne organizacione strukture, apatija, konflikti, represija... U takvoj klimi, zaposleni pokušavaju da se motivišu kroz pretnju, prinudu, izazivanje straha, kažnjavanje.

Korporativna kultura može biti „tajna formula uspeha”, ali i „tihi ubica”, zavisno od toga da li odgovara konkretnim okolnostima. Preduzeće neće dobro funkcionisati ako ne postoji razvijena mreža komunikacionih veza i ako nije uspostavljena povoljna korporativna kultura $u$ smislu privrženosti prema demokratskoj uključenosti svih. Sve dok zajedničke vrednosti ne postanu zajedničke svima ili bar većini zaposlenih, istina će uvek biti više individualna nego kolektivna. Zaposleni koji se nisu socijalizovali i nisu prihvatili kulturne vrednosti i verovanja preduzeća, ne mogu efikasno ni da izvršavaju svoje zadatke u njemu. Oni će uvek imati teškoća u komunikaciji i koordinaciji napora sa ostalim zaposlenima, i verovatno je da će biti u stalnim konfliktima sa njima usled među-sobnog nerazumevanja. Kada "mentalne modele” usvoje svi ili bar većina zaposlenih i dele ih, to snažno utiče na način na koji preduzeće posluje i kreira njegov poseban identitet. Sva uspešna preduzeća, po pravilu, imaju snažnu, jasno definisanu korporativnu kulturu i zajednički sistem vrednosti i verovanja koji dele svi zaposleni.

\section{ZAKLJUČCI}

Previše je primera koji govore o tome da su ogovaranja, dodvoravanja i spletkarenja uobičajeno, snažno oružje, da zaposleni okupljeni u sali sa šefom ili drugim autoritetom postaju vrlo nesigurni, nervozni, smušeni i nepoverljivi, da se interne komunikacije svode na to da se utvrdi šta kom radniku treba reći da bi on izvršio svoje zadatke, da se ljudi postavljaju na odgovorna i visoko rukovodeća mesta prema kriterijumima koji se ne mogu smatrati profesionalnim... Izgleda da je još uvek najvažnije za uspeh bliskost sa centrima moći, snalažljivost i veze, a najmanje važno sposobnost i znanje, rad i zalaganje. Vreme je da se greške činjene u prethodnim periodima isprave $i$ da se sadašnja shvatanja menjaju i menjaće se, sviđalo se to nekom ili ne. Oni koji to pre shvate i prihvate biće u ogromnoj prednosti. Moramo početi od sebe samih, i mentalnih promena kod nas, da bi smo menjali situaciju i da na putu tih promena pravimo što manje grešaka. Moramo više da mislimo na budućnost, da učimo od onih koji su ispred nas, da se oslobodimo političkih kriterijuma i neprofesionalizma u upravljanju. Umesto autoritarnosti, netolerantnosti, oslanjanja na društvene veze, naše menadžere moraju krasiti savremena praktična znanja i veštine, umeće dobrog organizovanja i poslovnog ponašanja - to je ono što nam treba!

Spoljašnja kontrola i pretnja kaznom, nisu jedina sredstva kojima se može učiniti da zaposleni ulažu napor i ostvaruju definisane ciljeve. Dobra interna povezanost zaposlenih i povoljna psihološka klima, snažna kultura i pripadnost firmi, garancija su veće angažovanosti i kvaliteta rada. (Džamić, 2016) Humanizacija rada je "conditia sine qua non" za bolju organizaciju i podizanje produktivnosti rada, a ovakav pristup je temeljna podloga kojom se ona može ostvariti. Zadovoljstvo na radu, visok radni moral, participativni menadžment, savetovanja i dobra komunikacija postaju sve važniji koncepti i čine osnovu svakog uspešnog (vrhunskog) poslovanja. Niko u preduzeću ne sme da se nalazi izvan radnog zajedništva, najmanje to treba da čini menadžment izolovanjem u svoje kancelarije, daleko od ljudi i kolega na poslu sa kojima upravlja i koje podržava. I uz ne baš najmoderniju tehnologiju, dobrom organizacijom i humanizacijom rada može se postići mnogo više, 
nego u uslovima visoke tehnologije, kada se o ljudima i njihovim potrebama ne vodi dovoljno računa.

Sadašnja praksa u mnogim našim preduzećima je da pojedinci, ekipe, odeljenja obavljaju svoje aktivnosti izolovano, u vakuumu, na različitim „talasnim dužinama”, ograđeni (odsečeni) jedni od drugih. Sve ovo je praćeno nedostatkom i neuspehom komunikacija, sukobima koji proizvode strah, intrige, tračeve, glasine, spletkarenja, a zaposleni čak i ne govore međusobno. Štete koje iz toga mogu da proisteknu su očigledne, zato umesto ovakve prakse bolje bi bilo podsticati komunikacije, stvarati uslove za neformalne razgovore, podsticati neprekidno učenje i napredovanje, uzdizanje.

lako su ljudi isticani kao naše najveće bogatstvo, do sada je malo toga činjeno na istraživanju njihovih potreba, motiva, konflikata i frustracija, istraživanju grupa, kulture, komunikacija. Mnoga naša preduzeća još uvek funkcionišu po Tajlorovom modelu, sa menadžmentom čiji je zadatak da razmišlja i radnicima koji su tu da rade i ne pitaju mnogo. Šta više, mnogi su duboko uvereni da je to pravi način da se preduzeće vodi. Došlo je vreme da se to shvatanje menja i menjaće se, kod svih onih koji žele uspeh na sve zahtevnijem tržištu.

\section{CITIRANA DELA}

Bećirović, S., Ljajić, S., Elfić-Zukorlić, E., \& Smailović, S. (2020). Značaj komunikacije sa zaposlenicima i njen utjecaj na motivaciju. Lingua Montenegrina, XIII/1(25).

Charney, C. (1996). Efikasan menadžer. Beograd: Grmeč - Privredni pregled.

Damnjanović, P., Suša, B., Škunca, D., Milenković, S., \& Ristić, Ž. (2012). Menadžment ljudskih resursa. Beograd: EtnoStil.

Džamić, V. (2016). Organizaciono ponašanje i korporativna kultura. Beograd: Univerzitet Singidunum. Inić, B. (2001). Uspeh Anite Rodik. Biznis Danas(63).

Nićin, S., Nićin, N., \& Grbić, V. (2014, 07 15). Noviji trendovi i programi motivacije zaposlenih. (Z. Čekerevac, Ur.) FBIM Transactions, 2(2), 235-243. doi:10.12709/fbim.02.02.02.23

Radić, V., \& Radić, N. (2015). Uticaj motivacije zaposlenih na performanse organizacije. Contemporary business and management, SYNTHESIS.

Rajkov, M., \& Sajfert, Z. (1999). Preduzetnički menadžment. Beograd: Fakultet organizacionih nauka.

Ristić, Z. (2005). Strategija upravljanja internim komunikacijama preduzeća, doktorska disertacija. Beograd: Ekonomski fakultet.

Received for publication: $\quad 01.10 .2020$

Revision received: $\quad 18.02 .2021$

Accepted for publication: $\quad$ 05.04.2021.

\section{Kako citirati ovaj rad? / How to cite this article?}

Style - APA Sixth Edition:

Ristić, Z., \& Damnjanović, A. (2021, 04 15). Upravljanje ljudskim resursima - Izazov novog milenijuma. (Z. Čekerevac, Ur.) FBIM Transactions, 9(1), 137-145. doi:10.12709/fbim.09.09.01.13

\section{Style - Chicago Sixteenth Edition:}

Ristić, Zoran, i Aleksandar Damnjanović. 2021. „Upravljanje ljudskim resursima - Izazov novog milenijuma." Urednik Zoran Čekerevac. FBIM Transactions (MESTE) 9 (1): 137-145. doi:10.12709/fbim.09.09.01.13. 
Style - GOST Name Sort:

Ristić Zoran i Damnjanović Aleksandar Upravljanje ljudskim resursima - Izazov novog milenijuma [Časopis] // FBIM Transactions / ur. Čekerevac Zoran. - Beograd : MESTE, 1504 2021. - 1 : T. 9. - str. 137-145.

Style - Harvard Anglia:

Ristić, Z. \& Damnjanović, A., 2021. Upravljanje ljudskim resursima - Izazov novog milenijuma. FBIM Transactions, 15 04, 9(1), pp. 137-145.

Style - ISO 690 Numerical Reference:

Upravljanje ljudskim resursima - Izazov novog milenijuma. Ristić, Zoran i Damnjanović,

Aleksandar. [ur.] Zoran Čekerevac. 1, Beograd : MESTE, 1504 2021, FBIM Transactions, T. 9, str. 137-145. 